FINAL PROJECT REPORT

\title{
U.S Department of Energy Pacific Region Clean Energy Application Center (PCEAC)
}

\author{
Award Number: \\ DE-EE0001105 \\ Sponsor: \\ DOE National Energy Technology Laboratory \\ Reporting Period \\ October, 2009 - September, 2013
}

Lead Investigators:

Dr. Tim Lipman and Prof. Dan Kammen

Energy and Resources Group, University of California - Berkeley

Dr. Vince McDonell and Prof. Scott Samuelsen

Advanced Power and Energy Program, University of California - Irvine

Prof. Asfaw Beyene

Industrial Assessment Center, San Diego State University

Prof. Ahmad Ganji

Industrial Assessment Center, San Francisco State University

Submitted to:

Joe Renk, Project Manager

Submitted on:

December 18, 2013

Revised Version: December 21, 2013 


\section{DISCLAIMER}

This report was prepared as an account of work sponsored by an agency of the United States Government. Neither the United States Government nor any agency thereof, nor any of their employees, makes any warranty, express or implied, or assumes any legal liability or responsibility for the accuracy, completeness, or usefulness of any information, apparatus, product, or process disclosed, or represents that its use would not infringe privately owned rights. Reference herein to any specific commercial product, process, or service by trade name, trademark, manufacturer, or otherwise does not necessarily constitute or imply its endorsement, recommendation, or favoring by the United States Government or any agency thereof. The views and opinions of authors expressed herein do not necessarily state or reflect those of the United States Government or any agency thereof. 
THE DOE AWARD NUMBER AND NAME OF THE RECIPIENT

\author{
DE-EE0001105
}

University of California - Berkeley

\title{
2 THE PROJECT TITLE AND NAME OF THE PROJECT DIRECTOR/PRINCIPAL INVESTIGATOR
}

\author{
Pacific Region Clean Energy Application Center \\ Dr. Timothy Lipman (lead PI), Prof. Daniel Kammen (UC Berkeley PIs) \\ Dr. Vince McDonell and Prof. Scott Samuelsen (UC Irvine PIs) \\ Prof. Asfaw Beyene (San Diego State Univ. PI) \\ Prof. Ahmad Ganji (San Francisco State Univ. PI)
}

\section{EXECUTIVE SUMMARY}

The U.S. Department of Energy Pacific Region Clean Energy Application Center (PCEAC) was formed in 2009 by the U.S. Department of Energy (DOE) and the California Energy Commission to provide education, outreach, and technical support to promote clean energy -- combined heat and power (CHP), district energy, and waste energy recovery (WHP) -- development in the Pacific Region. The region includes California, Nevada, Hawaii, and the Pacific territories.

The PCEAC was operated as one of nine regional clean energy application centers, originally established in 2003/2004 as Regional Application Centers for combined heat and power (CHP). Under the Energy Independence and Security Act of 2007, these centers received an expanded charter to also promote district energy and waste energy recovery, where economically and environmentally advantageous. The centers are working in a coordinated fashion to provide objective information on clean energy system technical and economic performance, direct technical assistance for clean energy projects and additional outreach activities to end users, policy, utility, and industry stakeholders.

A key goal of the CEACs is to assist the U.S. in achieving the DOE goal to ramp up the implementation of CHP to account for $20 \%$ of U.S. generating capacity by 2030 , which is estimated at a requirement for an additional $241 \mathrm{GW}$ of installed clean technologies. Additional goals include meeting the Obama Administration goal of $40 \mathrm{GW}$ of new CHP by 2020 , key statewide goals such as renewable portfolio standards (RPS) in each state, California's greenhouse gas emission reduction goals under $A B 32$, and Governor Brown's "Clean Energy Jobs Plan" goal of 6.5 GW of additional CHP over the next twenty years.

The primary partners in the PCEAC are the Department of Civil and Environmental Engineering and the Energy and Resources Group (ERG) at UC Berkeley, the Advanced Power and Energy Program (APEP) at UC Irvine, and the Industrial Assessment Centers (IAC) at San Diego State University and San Francisco State University. The center also worked with a wide range of affiliated groups and industry, government, NGO, and academic stakeholders to conduct a series of CHP education and outreach, project technical support, and related activities for the Pacific region.

Key PCEAC tasks have included:

- Preparing, organizing and conducting educational seminars on various aspects of CHP

- Conducting state baseline assessments for CHP

- Working with state energy offices to prepare state CHP action plans

- Providing technical support services including CHP/district energy project feasibility screenings

- Working with state agencies on CHP policy development

- Developing additional CHP educational materials 
The primary specific services that PCEAC has offered include:

- A CHP "information clearinghouse " website: http://www.pacificcleanenergy.org

- Site evaluations and potential projects screenings

- Assessment of CHP status, potential, and key issues for each state

- Information and training workshops

- Policy and regulatory guidance documents and other interactions

These services were generally offered at no cost to client groups based on the DOE funding and additional activities supported by the California Energy Commission, except for the in-kind staff resources needed to provide input data and support to PCEAC assessments at host sites. Through these efforts, the PCEAC reached thousands of end-users and directly worked with several dozen organizations and potential CHP "host sites" from 2009-2013. The major activities and outcomes of PCEAC project work are described below.

\section{A COMPARISON OF THE ACTUAL ACCOMPLISHMENTS WITH THE GOALS AND OBJECTIVES ESTABLISHED FOR THE PERIOD AND REASONS WHY THE ESTABLISHED GOALS WERE NOT MET}

\subsection{What we planned to accomplish this period (FY 2009-2013)}

This section covers the planned technical and scientific activities undertaken by the US Department of Energy Pacific Clean Energy Application Center in support of the project goals for the full project period. The informational/outreach and technical objectives and activities were established to provide analysis to inform policy decisions regarding CHP, WHP, and district energy within the states of California, Nevada, and Hawaii. Key activities that were planned for this period included those to:

- Conduct "tiger team" audits and feasibility studies for potential adoption of clean energy technologies at sites in California, Nevada, and Hawaii;

- Hold workshops and webinars for key stakeholders and market segments for clean energy applications;

- Maintain and update PCEAC web page including: adding new project profiles, updating news events, maintaining and adding external links, and updating webinars and workshop dates;

- Provide information and assistance in response to telephone and email inquiries from potential CHP developers, end-users, and other stakeholders

- Send a quarterly newsletter with key updates and events to the PCEAC Constant Contact database of regional contacts;

- Participate in key CEAC activities including CEAC teleconferences and DOE policy planning and development support activities;

- Provide policy reports to DOE and stakeholders on key policy issues such as the impacts of AB 32 "Cap and Trade" legislation, AB 1613 "Feed-In Tariff" legislation, the latest California Self-Generation Incentive Program rules, the California fiscal Impact of AB1150, etc.;

- $\quad$ Analyze the greenhouse gas emissions impacts and policy issues for CHP, WHP, and district energy systems in California;

- Analyze the jobs creation impacts of California Governor Brown's "Clean Energy Jobs Plan" 6.5 GW Goal for new CHP installations;

- Investigate the costs of metering for California SGIP Program installations; and 
- Establish the latest technical performance and installed costs of CHP, WHP, and district energy power systems in the Pacific region.

\subsection{What we actually accomplished this period (FY 2009-2013)}

The accomplishments for this period matched well with the planned accomplishments. All of the key goals for the project were met through the realization of these activities. During the project, the PCEAC team:

- Conducted "tiger team" audits and feasibility studies for potential adoption of clean energy technologies at sites in California, Nevada, and Hawaii (see more details in Section 5);

- Held workshops and webinars for key stakeholders and market segments for clean energy applications (see more details in Section 5);

- Maintained and periodically updated the PCEAC web page including: adding new project profiles, updating news events, maintaining and adding external links, and updating webinars and workshop dates;

- Provided information and assistance in response to telephone and email inquiries from potential CHP developers, end-users, and other stakeholders

- Sent quarterly newsletters with key updates and events to the PCEAC Constant Contact database of regional contacts;

- Participated in key CEAC activities including CEAC teleconferences and DOE policy planning and development support activities;

- Provided policy reports to DOE and stakeholders on key policy issues such as the impacts of $A B 32$ "Cap and Trade" legislation, AB 1613 "Feed-In Tariff" legislation, the latest California Self-Generation Incentive Program rules, the California fiscal Impact of AB1150, etc. (see more details in Section 5);

- Analyzed the "Greenhouse Gas Emissions Impacts and Policy Issues for Combined Heat and Power Systems in California;"

- $\quad$ Analyzed the "Jobs Creation Impacts of Governor Brown's Clean Energy Jobs Plan 6.5 GW Goal for New Combined Heat and Power Installations;"

- Investigated the "Costs of Metering for California SGIP Program Installations;" and

- Worked to establish the latest technical performance and installed costs of CHP, WHP, and district energy power systems in the Pacific region.

\subsection{How we did compared to our plan}

The project was completed as planned with all project work completed by the project end date of September 30, 2013.

5 PROJECT ACTIVITIES CONDUCTED FOR THE ENTIRE PERIOD OF FUNDING, INCLUDING ORIGINAL HYPOTHESES, APPROACHES USED, PROBLEMS ENCOUNTERED AND DEPARTURE FROM PLANNED METHODOLOGY, AND AN ASSESSMENT OF THEIR IMPACT ON THE PROJECT RESULTS. INCLUDE, IF APPLICABLE, FACTS, FIGURES, ANALYSES, AND ASSUMPTIONS USED DURING THE LIFE OF THE PROJECT TO SUPPORT THE CONCLUSIONS.

The following sections describe and summarize the hypotheses/premises, activities, approaches, and key outcomes of the central PCEAC tasks in greater detail.

\subsection{Education and Outreach Activities}

Education and outreach activities formed a core set of PCEAC activities - identified as "Task 1" 
activities in the original project proposal. These activities included hosting workshops and webinars, delivering additional presentations at meetings, and operating the PCEAC website, as well as responding to frequent additional requests for information by phone and email.

Additionally, several CHP case study project profiles were developed for example projects in the Pacific region. The following lists summarize the most significant of the activities.

\section{Target Market Workshops}

- Waste Heat Recovery for Power and Heat (Co-supported by PCEAC in Chicago, IL, Sept. 29-30, 2010)

- Combined Heat and Power for California - What's New? (Downey - Nov. 17, 2010)

- Combined Heat and Power for California - What's New? (SF - Dec. 8, 2010)

- CHP and DG for Secure Power for Data Centers (Sept. 7, 2011)

\section{Target Market Webinars}

- Overview of Stationary Fuel Cell Systems (Sept. 28, 2010)

- Introduction to Waste Heat to Power (May 25, 2011)

- California Interconnection and Rule 21 (Dec. 8, 2011)

- CHP for California Hospital Applications, California (April 4, 2013)

- CHP for California Wastewater Treatment Applications (June 15, 2013)

\section{Presentations at End-User Workshops and Conference Events:}

- CA CHP and PCEAC Overview, CADER (April 28, 2010)

- CHP and District Energy in California and the U.S. (June 21, 2011)

- CHP Experience in California: Inputs from the Field (March 22, 2012)

- Clean Energy Market and Policy Development, San Diego, CA (Feb. 2013)

- Presented four DG/CHP cast studies, Irvine, CA (Feb. 2013)

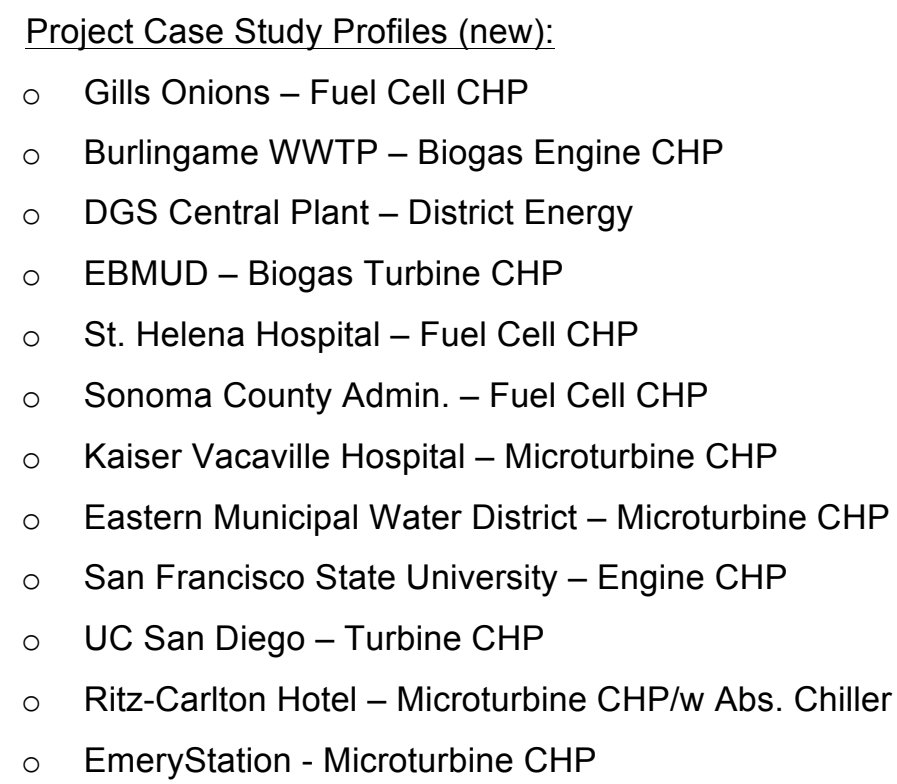


Website Usage Statistics:

\begin{tabular}{|l|c|c|c|c|c|}
\hline $\begin{array}{l}\text { Project } \\
\text { Year }\end{array}$ & $\begin{array}{c}\text { Total } \\
\text { Number of } \\
\text { Page Views } \\
\text { on CEAC } \\
\text { Website }\end{array}$ & $\begin{array}{c}\text { Number of } \\
\text { Unique } \\
\text { Visitors to } \\
\text { CEAC } \\
\text { Website }\end{array}$ & $\begin{array}{c}\text { Number of } \\
\text { Conference } \\
\text { Presentation } \\
\text { s Viewed or } \\
\text { Downloaded }\end{array}$ & $\begin{array}{c}\text { Number of } \\
\text { Project } \\
\text { Profiles / } \\
\text { Case } \\
\text { Studies } \\
\text { Viewed or } \\
\text { Downloaded }\end{array}$ & $\begin{array}{c}\text { Number of } \\
\text { Regional } \\
\text { Roadmaps / } \\
\text { Action Plans } \\
\text { Viewed or } \\
\text { Downloaded }\end{array}$ \\
\hline FY 2010* & 78,282 & 16,665 & 30,503 & 5,982 & 2,366 \\
\hline FY 2011 & 6,446 & 1,688 & n.r. & n.r. & n.r. \\
\hline FY 2012 & 7,572 & 2,062 & n.r. & n.r. & n.r. \\
\hline FY 2013 & 8,723 & 2,414 & n.r. & n.r. & n.r. \\
\hline
\end{tabular}

Note: * Figures reported for FY 2010 used a prior version of web-traffic analytic software that over-estimated actual web visits by actual people (versus automated hits by "web-bots"). The figures for FY 2011-13 are believed to be accurate in terms of actual human visitors.

\subsubsection{Original Hypothesis/Premise}

The premise behind these activities is that a suite of outreach activities, including directed outreach to key end-user groups, can be the most effective way to provide education and outreach efforts for the region.

\subsubsection{Approach}

The approach involved both widespread (website and newsletter "e-blasts") and more targeted outreach and education efforts. In all cases efforts were made to present the most up-to-date and technically correct information possible.

\subsubsection{Problems Encountered}

Few problems were encountered in this activity, however one potential end-user workshop on WHP that was contemplated was not held due to a lack of consensus on a clear agenda and the best way to promote the complex topic of WHP for industries other than refineries.

\subsubsection{Departures from Planned Methodology}

No departures from planned methodology.

\subsubsection{Assessment of Impact on project results}

While difficult to fully assess, these education and outreach efforts were well attended and with significant follow-up activities, in several cases leading to project screening activities described below.

\subsection{Direct Project Assistance and Feasibility Studies}

A key PCEAC activity, identified as "Task 2" in the original project proposal, consisted of providing direct project assistance to potential CHP projects by performing CHP site audits showing potential system sizing and technical and economic performance. A total of 40-45 of these assessments were conducted by the PCEAC, with most recommending a potential CHP/WHP/district energy system with varying projected payback times. Direct project assistance 
provided by the PCEAC led to the installation (or expected installation for "projects in the pipeline") of approximately 15-20+ MW of new CHP in the region. A table of CHP assessments where CHP was recommended ( 35 total sites) is shown below. These assessments all led to detailed assessment reports that were provided to the study "clients" a few months after each assessment, on a confidential basis. Some of these projects have already been or are being implemented, while many others are still being investigated more deeply but based on interest developed through these site feasibility studies.

\begin{tabular}{|c|c|}
\hline Project Host Site Name & Location (City, State) \\
\hline Clougherty Packing & Vernon, CA \\
\hline Livermore WWTP & Livermore, CA \\
\hline Chula Vista Veteran's Home & Chula Vista, CA \\
\hline Caesar's Casino Laundry & Las Vegas, NV \\
\hline Campbell Soup & Dixon, CA \\
\hline Global Oakland & Oakland, CA \\
\hline Land o' Lakes & Orland, CA \\
\hline Yucaipa WWTP & Yucaipa, CA \\
\hline Tracy WWTP & Tracy, CA \\
\hline Tulare WWTP, CA & Tulare, CA \\
\hline Pacific Ethanol & Stockton, CA \\
\hline Manchester Grand Hyatt & San Diego, CA \\
\hline Sheraton Waikiki & Honolulu, HI \\
\hline Westin Moana Surfrider & Honolulu, HI \\
\hline Sheraton Princess Kaiulani & Honolulu, HI \\
\hline Kauai Resort & Kauai, $\mathrm{HI}$ \\
\hline Morgan Ceramics & Hayward, CA \\
\hline Richmond CDPH & Richmond, CA \\
\hline Pacific Ethanol & Stockton, CA \\
\hline 555 California St. & San Francisco, CA \\
\hline Wysong Village & Alhambra, CA \\
\hline Bentley Prince Street & City of Industry, CA \\
\hline Ventura Foods & Ontario; CA \\
\hline Esterline Defense Technologies & Coachella, CA \\
\hline Baxter Bioscience & Newbury Park, CA \\
\hline University Retirement Community & Davis, CA \\
\hline Santa Cruz Waste Water Treatment & Santa Cruz, CA \\
\hline Hawaii-Meadow Gold & Honolulu, $\mathrm{HI}$ \\
\hline Hawaii-FCH Enterprises & Honolulu, $\mathrm{HI}$ \\
\hline Honouliuli WWTP, HI & Honolulu, $\mathrm{HI}$ \\
\hline Sand Island WWTP, HI & Honolulu, HI \\
\hline Concentric Power - Client & Monterey, CA \\
\hline Advanced Hybrid Renewable & Lancaster, CA \\
\hline P\&W Rocketdyne & Canoga Park, CA \\
\hline Uniweb, Inc. & Corona, CA \\
\hline
\end{tabular}




\subsubsection{Original Hypothesis/Premise}

The premise behind this activity is that if an initial site screening can be done at no cost to the host site, the initial findings if positive may lead to additional interest and potential project development at the host site.

\subsubsection{Approach}

This task involves identifying promising host sites, obtaining the clear interest of a "high level decision-maker" at the site, performing a pre-qualification study, issuing a letter offering the full project screening (if pre-qualification is favorable), performing the inperson (typically half day to full day) site assessment with a "tiger team" from the PCEAC, performing the analysis, issuing the draft report (first for DOE review followed by the client), and finally responding to any comments for the final assessment report.

\subsubsection{Problems Encountered}

In some cases, initial interest in a screening at a host site was not followed with the promise of providing the needed data to do the full project assessment, after the prequalification was completed. This happened in only a few cases.

\subsubsection{Departures from Planned Methodology}

No departures from planned methodology except in one or two cases the initial prequalification steps were inadvertently skipped as the new procedures were being learned and adopted. This did not materially affect the results of those studies.

\subsubsection{Assessment of Impact on project results}

This activity and additional technical information for potential host sites has led directly to greater interest in pursuing projects, the development of more detailed "investment grade" analyses, issuance of bids for actual projects, and actual project installation of 1520+ MW of new CHP capacity.

\subsection{Policy Study: SGIP Metering Costs}

The following sections describe a series of analytical efforts and reporting activities related to $\mathrm{CHP} / \mathrm{WHP} /$ district energy policy and market development activities in the region (identified as "Task 3" activities in the original project proposal).

The purpose of this "SGIP Metering Costs" paper was to characterize the range of costs associated with additional electricity, fuel, and thermal metering of combined heat and power (CHP) systems installed in California as required by the California Self-Generation Incentive Program (SGIP). Such metering is required for performance monitoring of systems to assure that they are meeting the minimum program efficiency requirements, as well as achieving the expected capacity factors over the 5-year payout term of the SGIP incentive payments. We find that the marginal costs of metering are driven by the need for thermal metering. The marginal costs range from about $\$ 8,500$ for small diameter in-line metering, to $\$ 70,000$ for systems requiring large diameter ultrasonic flow meters. For metering thermal use, costs are driven by technology selection, and complexity of installation.

\subsubsection{Original Hypothesis/Premise}

The original intent of the investigation was to determine the metering cost impacts to $\mathrm{CHP}$ projects in the State of California as a result of satisfying incentive program requirements.

\subsubsection{Approach}

Costs associated with metering technologies required under the SGIP were collected using interviews, available literature, technical reports, and estimating books. This data would then be analyzed to determine a range of costs for metering under the SGIP. 


\subsubsection{Problems Encountered}

Data availability from published sources was sparse. Interviews with available suppliers only provided limited data as a result of the sensitivity of some cost information due to market competition. As a result, average labor costs and recurring service fees had to be estimated or excluded from the analysis where no educated basis for their inclusion could be found.

\subsubsection{Departures from Planned Methodology}

With the exception of the unavailability of certain cost information, the planned methodology was followed for this technical report. The most significant change to the approach was to assess marginal costs compared to non-SGIP eligible facilities, rather than total metering costs for SGIP qualified CHP installations.

\subsubsection{Assessment of Impact on project results}

Due to the unavailability of some cost data, confidence decreases in the marginal cost increases for metering as a result of the SGIP program. As some cost data was excluded, we anticipate that on average, the study slightly under-estimates the marginal costs of metering for some CHP installations.

\subsection{Policy Study: CA CHP/WHP Jobs Analysis}

The analysis by the PCEAC intended to investigate the jobs creation benefits of the Governor Jerry Brown's 6,500 MW goal for CHP in California. The analysis primarily relies on the Jobs and Economic Development Impact (JEDI) Model ${ }^{1}$ developed by the U.S. DOE's National Renewable Energy Laboratory but also examines potential "economic-multiplier" impacts from the reinvestment of economic savings achieved by CHP host sites.

\subsubsection{Original Hypothesis/Premise}

We hypothesized that, in addition to economic benefits as a result of durable goods purchases and construction labor required to install a new CHP facility, greater implementation of CHP would have economic multiplier effects as a result of reduced energy expenditures by firms.

\subsubsection{Approach}

The analysis primarily relies on the Jobs and Economic Development Impact (JEDI) Model developed at NREL, in addition to a simple spreadsheet model to help assess economic multiplier impacts due to re-investment of economic savings.

\subsubsection{Problems Encountered}

Economic Input-Output tables at regional levels are not publicly available, making the assessment of economic impacts specific to the California market challenging. Some labor and equipment cost multipliers are available from some commercial resources, but these do not account for all economic impacts within a given region. In addition, the type and market share of each CHP technology installed under the $6500 \mathrm{MW}$ goals outlined by the Governor's plan are uncertain, and would impact the overall economic impact of $\mathrm{CHP}$ technologies installed. JEDI was originally designed to model the impacts of intermittent renewable technologies, and centralized combined cycle gas turbines (CCGT), and not CHP. Modifications were made to the assumptions used in JEDI to support analysis of the CHP market.

\subsubsection{Departures from Planned Methodology}

There were no significant departures from the planned methodology for this task.

\subsubsection{Assessment of impact on project results}

Impacts to project results were primarily a result of data availability, reducing certainty

\footnotetext{
${ }^{1}$ http://www.nrel.gov/analysis/jedi/about_jedi.html
} 
and confidence in results for broader economic impacts and jobs creation as a result of increased CHP adoption.

\subsection{Policy Study: AB1150 Institutional Potential Impact}

This analysis summarizes the potential economic benefits to California state institutions of the potential extension of the SGIP program through AB1150. What is analyzed is the amount of combined heat and power (CHP) that might be adopted by state-operated entities during the oneyear extension of the program, and the associated costs and benefits to the state. In addition to CHP, the SGIP also incentivizes small-scale wind power projects that also would be expected under the program extension. But these are not likely to be installed in significant numbers at state-operated facilities.

\subsubsection{Original Hypothesis/Premise}

The extension of incentive programs for clean energy technologies presents both costs and benefits for state agencies. The goal of this report was to assess those costs and benefits, and determine if the benefits of the extension of SGIP would justify the costs of program management for state owned facilities.

\subsubsection{Approach}

First order estimates of savings to state agencies and institutions were generated using estimates of CHP market growth from various sources. All sites were assumed to be of uniform capacity with similar payback periods, lifespans, operations and maintenance (O\&M) costs and capacity factors. In reality these values will be different for every installation, but the operation and performance of systems is site specific and outside the scope of this analysis. Assuming that the discounted payback period includes repayment of capital costs and ongoing O\&M costs; each successive time period beyond the initial payback period results in benefits equal to the capital cost of the project minus the ongoing average of O\&M costs. Using an economic model of CHP system performance, we calculated the direct benefits of CHP system installation compared to the cost of incentives.

\subsubsection{Problems Encountered}

The analysis did not include a valuation of societal benefits as a result of installation of $\mathrm{CHP}$ at state facilities. Further, the analysis is of state owned facilities that do not qualify for the Federal investment tax credit. If owned by a third party, the 10 percent ITC applies.

\subsubsection{Departures from Planned Methodology}

There were no significant departures from the planned methodology.

\subsubsection{Assessment of Impact on project results}

The problems encountered mean the analysis does not take into account all benefits and costs associated with the installation of CHP at state owned facilities. An analysis of the lifecycle cost-effectiveness of CHP installations would need to take into account all benefits and costs to result in an accurate portrayal of system economics. This is a challenge for the assessment of all CHP installations, and is not unique to the assessment of the impacts of AB1150. This study served as a first order analysis of the proposed extension, showing in terms of direct costs and benefits, the extension would be beneficial.

\subsection{Policy Study: Greenhouse Gas Emissions Impacts and Policy Issues for Combined Heat and Power Systems in California}

The purpose of this activity was to assess and summarize the current and future role of combined heat and power (CHP) in reducing energy intensity and greenhouse gas (GHG) emissions in California, and to identify key factors that could impact further market development of CHP. 


\subsubsection{Original Hypothesis/Premise}

The research was aimed at determining how the declining cap on GHG emissions under California Cap and Trade legislation will impact avoided emissions from increased adoption of CHP installations. Additionally, the work investigated the financial impacts of Cap and Trade regulations and compliance requirements on CHP installations.

\subsubsection{Approach}

Using existing data from models of the California electricity supply for Cap and Trade Scenarios, a spreadsheet tool was created to assess the average avoided emissions from CHP installations, and assess avoided GHG emissions from CHP as the GHG emissions intensity decreased on the California electrical grid.

\subsubsection{Problems Encountered}

While the average GHG emissions intensity of the California electricity grid under carbon reduction scenarios was available, hourly and sub-hour estimates of GHG intensity were not available. As a result, a simplified model of CHP operation based on capacity factors was used instead of an hourly operation schedule that took into account peak and offpeak electricity intensity and TOU and PDP tariffs for commercial customers.

\subsubsection{Departures from Planed Methodology}

There were no significant departures from the planned methodology for this task.

\subsubsection{Assessment of Impact on project results}

The use of average GHG intensity for the bulk electrical grid results in conclusions that are applicable for informing broad policy decisions, and to show the hypothetical implications of current policy as it pertains to CHP.

\subsection{Policy Study: SGIP Program Description}

This paper highlights the key changes and new program rules for the 2011-2014 California SelfGeneration Incentive Program (SGIP). The paper is intended to assist potential CHP host sites, project developers, and others with regard to understanding the latest SGIP program rules by highlighting changes in eligibility requirements and modifications from previous iterations of the SGIP.

\section{Products developed under the award and technology transfer activities:}

\section{Research Papers}

- Timothy Lipman, Raphaelle Richarde, Vincent McDonell, Asfaw Beyene, and Ahmad Ganji (2011), "2011 Combined Heat and Power Baseline Analysis and Action Plan for the California Market," Prepared for the U.S. Department of Energy, March 30.

- Timothy Lipman, Raphaelle Richarde, Vincent McDonell, Asfaw Beyene, and Ahmad Ganji (2011), "2011 Combined Heat and Power Baseline Analysis and Action Plan for the Hawaii Market," Prepared for the U.S. Department of Energy, March 30.

- Timothy Lipman, Raphaelle Richarde, Vincent McDonell, Asfaw Beyene, and Ahmad Ganji (2011), "2011 Combined Heat and Power Baseline Analysis and Action Plan for the Nevada Market," Prepared for the U.S. Department of Energy, March 30.

- Timothy Lipman, Sean Sevilla, and Raphaelle Richarde (2011), "Analysis of the Fiscal Impact of AB1150 to California State Institutions," Prepared for the U.S. Department of Energy and the California Energy Commission, August 17.

- Timothy Lipman and Sean Sevilla (2012), "California SGIP and CHP: Recent History and Current Status of the California Self-Generation Incentive Program," Prepared for the 
U.S. Department of Energy, June 12.

- Timothy Lipman and Sean Sevilla (2013), "Metering Costs for Distributed Generation Under the California Self-Generation Incentive Program," Prepared for the U.S. Department of Energy, September 15.

- Timothy Lipman (2013), "Summary of Recent PCEAC Combined Heat and Power Assessments in Hawaii," Prepared for the U.S. Department of Energy, September 30.

\subsection{Additional Publications}

- Lipman, Timothy and Vincent McDonell (2012), "California Clean Energy Policy Status and Market Opportunity Update," District Energy, Vol. 3rd Quarter: 74-75.

- Project feasibility assessment reports (confidential to client - approximately 45 reports produced with $\sim 40$ recommending potential CHP installations).

\subsection{Web site or other Internet sites that reflect the results of this project}

Website operated from 2009-2013: www.pacificcleanenergy.org

\subsection{Networks or collaborations fostered}

- Berkeley Lab

- Sempra

- PG\&E

- SMUD

- CA Clean DG coalition

- Endurant Energy

- US Energy Association

- USCHPA

- Heat is Power

- International District Energy Association

- The Gas Company

- California Stationary Fuel Cell Collaborative

\subsection{Technologies/Techniques}

None

\subsection{Inventions/Patent Applications, licensing agreements}

None

6.6 Other products, such as data or databases, physical collections, audio or video, software or netware, models, educational aid or curricula, instruments or equipment.

- Constant contact database of Pacific Region CHP/WHP/district energy stakeholders. 


\section{$7 \quad$ Acknowledgements}

The PCEAC team would like to gratefully acknowledge several key organizations and individuals listed below, as well as all of those who served on the PCEAC Advisory Group during this project term. The PCEAC would like to specifically thank Bob Gemmer, Katrina Pielli, Patti Garland, Joseph Renk, and Bonnie Dowdell from U.S. DOE; Linda Kelly, Art Soinski, Bryan Neff, and Pramod Kulkarni from the California Energy Commission; Ted Bronson from Power Equipment Associates; Bruce Hedman, Ken Darrow, and Anne Hampson from ICF; Rob Thornton and Laxmi Rao at IDEA; administrative support staff at UC Berkeley, UC Irvine, San Diego State University, and San Francisco State University; and many others for their support of this effort. 